\title{
Synthesis and evaluation of silver nanoparticles using Cymodocea rotundata against clinical pathogens and human osteosarcoma cell line
}

\author{
Jayanthi Abraham*, Shantanu Saraf, Vakas Mustafa, Yugal Chaudhary, Silambarasan Sivanangam \\ Microbial Biotechnology Lab, School of Bioscience and Technology, VIT University, Vellore-632014, Tamil Nadu, India.
}

\begin{tabular}{l} 
ARTICLE INFO \\
\hline Article history: \\
Received on: $27 / 02 / 2017$ \\
Accepted on: 19/04/2017 \\
Available online: $30 / 06 / 2017$ \\
\hline Key words: \\
Silver nanoparticles, \\
Cymodocea rotundata, FTIR, \\
SEM, MG63 cell line.
\end{tabular}

\section{INTRODUCTION}

Over the years the occurrence of the infectious diseases caused by the different pathogenic bacteria has been escalating and the researchers are searching for new antibacterial agents (Rai et al., 2009). In the current scenario, nanoscale materials have emerged as novel antimicrobial agents owing to their high surface area to volume ratio and the unique physical and chemical properties. Different types of nanomaterials like copper, titanium, zinc, alginate, gold, magnesium and silver have come up but silver nanoparticles (AgNPs) has been promising and proved to be most effective against bacteria and other eukaryotic microorganisms (Gong et al., 2007). The silver nanoparticles have also found diverse applications such as coatings for medical devices, wound dressings, silver nanoparticles impregnated textile fabrics, etc. the advantage of using silver nanoparticles

\footnotetext{
* Corresponding Author

Jayanthi Abraham, School of Bioscience and Technology,

VIT University, Vellore-632014, Tamil Nadu, India.

Email: jayanthi.abraham @gmail.com
}

for impregnation is that there is continuous release of silver ions $\left(\mathrm{Ag}^{+}\right)$and the devices can be coated by both inner and outer side hence, enhancing its antimicrobial efficacy. The burn wounds treated with silver nanoparticles shows better cosmetic appearance and scarless healing. In the last decade, biosynthesis of met al nanoparticles is a growing need to develop clean, nontoxic chemicals, environmentally benign solvents and renewable materials and hence the focus turned towards 'green' chemistry and bioprocesses. The synthesis of AgNPs through bacteria, fungi, yeast and plant extracts would benefit from the development of clean, nontoxic and environmentally acceptable 'green chemistry' procedure (Bhattacharya and Rajinder, 2005). Recently, Thirunavoukkarasu et al. (2013) reported the potential of leaf extract of Desmodium gangeticum in reducing aqueous $\mathrm{Ag}^{+}$to $\mathrm{Ag}^{0}$ ions and the rapid formation of eco-friendly AgNPs with well defined dimensions in the size range of 18-39 $\mathrm{nm}$. Logeswari et al. (2013) reported that the AgNPs were synthesized from a silver nitrate solution by commercially available plant powders such as Solanum tricobatum, Syzygium cumini, Centella asiatica and Citrus sinensis. 
The AgNPs also showed potent cytotoxic effect against MCF-7 breast cancer cell lines with an $\mathrm{IC}^{50}$ value of $67 \mu \mathrm{g} \mathrm{ml}^{-1}$ by the MTT assay. In the present research, AgNPs have been synthesized using Cymodocea rotundata extract. At the same time in vitro antioxidant, antimicrobial and cytotoxic effects of green synthesized silver nanoparticals were evaluated. To our knowledge, this is the first report on the synthesis of AgNPs using Cymodocea rotundata extract.

\section{MATERIALS AND METHODS}

\section{Sample preparation for synthesis of silver nanoparticles}

Fresh Cymodocea rotundata (Sea grass) was collected from Thondi coastal area $99^{\circ} 44^{\prime \prime} \mathrm{N}$ and $7910^{\circ} 45^{\prime}$ E situated in Palk Strait region of Tamilnadu. The sample was washed thoroughly with distilled water and was uniformly cut it into small pieces. The leaf extract was prepared by boiling $20 \mathrm{~g}$ of fresh Cymodocea rotundata chopped samples in $100 \mathrm{ml}$ of sterile distilled water for $5 \mathrm{~min}$, cooled and filtered. The extract was stored at $4{ }^{\circ} \mathrm{C}$ for further experiments. This filtrate was used as a reducing as well as stabilizing agent for $1 \mathrm{mM}$ of silver nitrate $\left(\mathrm{AgNO}_{3}\right)$ (Korbekandi et al., 2013).

\section{Biosynthesis of silver nanoparticles}

The silver nitrate, A.R., used in this study was obtained from Himedia Laboratories Pvt. Ltd., Mumbai, India. $10 \mathrm{ml}$ suspension of the leaf extract was added to $90 \mathrm{ml}$ aqueous solution of $\mathrm{AgNO}_{3}(1 \mathrm{mM})$ solution for the reduction from $\mathrm{Ag}^{+}$to $\mathrm{Ag}^{0}$ nanoparticles by incubation at $35{ }^{\circ} \mathrm{C}$ for about $24 \mathrm{~h}$. The primary detection of synthesized AgNPs was carried out in the reaction mixture by observing the colour change of the medium from greenish to dark brown (Thirunavoukkarasu et al., 2013).

\section{Characterization of silver nanoparticles}

The bioreduction of the $\mathrm{Ag}$ in solution was monitored by periodic sampling of aliquots $(2 \mathrm{ml})$. The absorption spectra of the samples were taken 300 to $600 \mathrm{~nm}$ using a UV-Vis spectrophotometer (HITACHI, Model U-2800 spectrophotometer). The deionized water was used as the blank. The sample was air dried and was characterized by atomic force microscopy (Model-Nanosurf easyscan 2 AFM, made in Switzerland) for its detailed morphology and size. Scanning electron microscope (SEM) was employed for the analysis of size and shape of AgNPs.

The AgNPs sample was mounted on specimen stubs with double-sided adhesive tape and coated with gold in a sputter coater to avoid charging and was examined under SEM (Zeiss Evo 18). The air dried powder of AgNPs was diluted with potassium bromide in the ratio of 1:100 and the spectrum which was recorded in FTIR in the range of $4000-500 \mathrm{~cm}^{-1}$ at a resolution of $4 \mathrm{~cm}^{-1}$. To check phase formation and purity, XRD patterns were recorded using powder X-ray diffractometer (Model-D8 Advance, made in BRUKER Germany) (Chakraborty et al., 2016).

\section{In vitro antioxidant assays (DPPH free radical scavenging} assay)

DPPH radical scavenging assay for AgNPs was performed at concentration of AgNPs $1 \mathrm{mg} \mathrm{ml}^{-1}$ which were separately mixed with $3 \mathrm{ml}$ of $0.1 \mathrm{mM}$ DPPH and incubated in dark for $15 \mathrm{~min}$. After incubation, the absorbance of the samples was measured by using UV-vis spectrophotometer at $517 \mathrm{~nm}$ against methanol as blank (Abdel-Aziz et al., 2014). Ascorbic acid was used as standard and DPPH methanol reagent without sample was used as control and percentage of inhibition was calculated by the following formula.

$\%$ of inhibition $=$ Absorbance of control-Absorbance of test/Absorbance of control

\section{Antimicrobial activity}

The AgNPs synthesized from Cymodocea rotundata was tested for their antimicrobial activity by well diffusion method against pathogenic organisms which were Escherichia coli, Pseudomonas aeruginosa, Enterococcus sp., Shigella sp., Salmonella sp., Staphylococcus aureus, Klebsiella pneumoniae and Proteus mirabilis obtained from Microbial Biotechnology laboratory, VIT University. The pure cultures of the organism were sub cultured on nutrient broth at $35^{\circ} \mathrm{C}$ on rotary shaker at $120 \mathrm{rpm}$. Each strain was swabbed uniformly on the individual plates using sterile cotton swab. Wells of size $6 \mathrm{~mm}$ have been made on Muller-Hinton agar plates using gel puncture. Using micropipette $25 \mu 1,50 \mu 1,75 \mu 1$ and $100 \mu \mathrm{l}$ of the sample of nanoparticles solution were poured into wells on all plates. After incubation at $35{ }^{\circ} \mathrm{C}$ for $18 \mathrm{~h}$, the different levels of zone of inhibition were measured (Chakraborty et al., 2016)

\section{Anticancer effect of AgNPs}

The human osteosarcoma cell line (MG63) was obtained from National Centre for Cell Science (NCCS), Pune and grown in Eagles Minimum Essential Medium (EMEM) containing 10\% fet al bovine serum (FBS). All cells were maintained at $37{ }^{\circ} \mathrm{C}, 5 \%$ $\mathrm{CO}_{2}, 95 \%$ air and $100 \%$ relative humidity. Maintenance cultures were passaged weekly, and the culture medium was changed twice a week.

In order to determine the cytotoxic effect of newly synthesized AgNPs, MTT dye reduction assay was performed on human osteosarcoma cell line (MG63) using increasing concentrations (12.5-200 $\mathrm{g} \mathrm{ml}^{-1}$ ) of AgNPs. The result of the assay depends on the reduction of MTT to a blue colored product by mitochondrial dehydrogenase, an enzyme present in the mitochondria of viable cells. For experimental settings, osteosarcoma cells were harvested and cultured, at a density of $1 \times 10^{5}$ cells ml ${ }^{-1}$ and incubated for $48 \mathrm{~h}$ in $5 \% \mathrm{CO}_{2}$ at $37{ }^{\circ} \mathrm{C}$ with the increasing concentrations of $\operatorname{AgNPs}(12.5,25,50,100$ and $200 \mu \mathrm{g} \mathrm{ml}^{-1}$ ). After the treatment of AgNPs, $15 \mu \mathrm{l}$ of MTT (5 $\mathrm{mg} / \mathrm{mL}$ in PBS) was added to each well and the plate was further incubated for $4 \mathrm{~h}$ at $37{ }^{\circ} \mathrm{C}$ in $5 \% \mathrm{CO}_{2}$. The resulting blue component (reduction of tetrazolium salt of MTT by mitochondrial dehydrogenase) was dissolved in $100 \mu \mathrm{l}$ dimethyl sulfoxide 
(DMSO) and then measured the absorbance at $570 \mathrm{~nm}$ using micro plate reader. The percentage of cell inhibition was determined using the following formula (Mosmann et al., 1983; Monks et al., 1991).

$\%$ Cell Inhibition $=100-$ Abs $($ sample $) / A b s($ control $) \times 100$.

\section{RESULTS AND DISCUSSION}

In this study, the formation of AgNPs by extract of Cymodocea rotundata was investigated. The reaction started with in first hour of the incubation with $1 \mathrm{mM} \mathrm{AgNO}_{3}$. This was confirmed by the appearance of brown colour in the reaction mixture. It is well known that silver nanoparticles exhibit a yellowish brown color in aqueous solution due to excitation of surface plasmon vibrations in AgNPs (Jae and Beom, 2009). Biosynthesis of AgNPs from $\mathrm{AgNO}_{3}$ solution was confirmed by UV-vis spectra studies, with the colour change from greenish to brown and recorded maximum absorbance at $420 \mathrm{~nm}$ (Figure 1). The observation indicates the release of proteins into solution by Cymodocea rotundata by a possible mechanism through reduction of the met al ions present in the solution. Similar observations were also reported in Solanum tricobatum, Syzygium cumini, Centella asiatica and Citrus sinensis. AFM micrographs of synthesized AgNPs are presented in Figure 2. It is clear that most of the AgNPs were spherical in shape with particle sizes of 24.2 $\mathrm{nm}$. Scanning electron microscopy (SEM) and energy-dispersive $\mathrm{X}$-ray microanalysis (EDX) observation gained further insight into the features of the silver nanoparticles. The synthesized AgNPs were spherical in shape as observed in the SEM image (Fig. 3a) and this confirmed the shape of AgNPs obtained in the AFM image. EDX analysis also showed a peak in the silver region, confirming the formation of silver nanoparticles (Figure $3 \mathrm{~b}$ ) and the optical absorption peak is observed approximately at $2.6 \mathrm{keV}$. The typical optical absorption between $2-4 \mathrm{keV}$ confirms the metallic nanoparticles due to surface plasmon resonance (Thirunavoukkarasu et al., 2013). Figure 4 shows the FTIR spectrum recorded from the air dried powder of AgNPs formed with Cymodocea rotundata extract. Peak at $3439 \mathrm{~cm}^{-1}$ and 1631 $\mathrm{cm}^{-1}$ corresponds to $\mathrm{N}-\mathrm{H}$ stretching and bending vibrations, respectively in amines from proteins of Cymodocea rotundata. The peak at $1087 \mathrm{~cm}^{-1}$ is attributed to $\mathrm{C}-\mathrm{O}$ stretching from ester and ether allowing to functional groups of proteins and metabolites covering the AgNPs. The overall observation confirms the presence of protein in the samples of AgNPs. It is reported earlier that proteins can bind to nanoparticles either through free amine groups or cysteine residues in the proteins (Gole et al., 2001) and therefore the stabilization of the AgNPs by protein is a possibility. Further studies were carried out using X-ray diffraction to confirm the crystalline nature of the particle and the XRD pattern obtained has been represented in Figure 5. The XRD pattern showed four intense peaks in the whole spectrum of $2 \theta$ value ranging from 30 to 80 .

The AgNPs formed in our experiments were in the form of nanocrystals, as evidenced by the peaks at $2 \theta$ values of $38.25^{\circ}$, $46.37^{\circ}$ and $77.62^{\circ}$ corresponding to 111,200 and 311 planes for silver, respectively. The three intense peaks were observed in the spectrum agree to the Braggs's reflection of silver nanocrystals as reported by Lu et al. (2003).

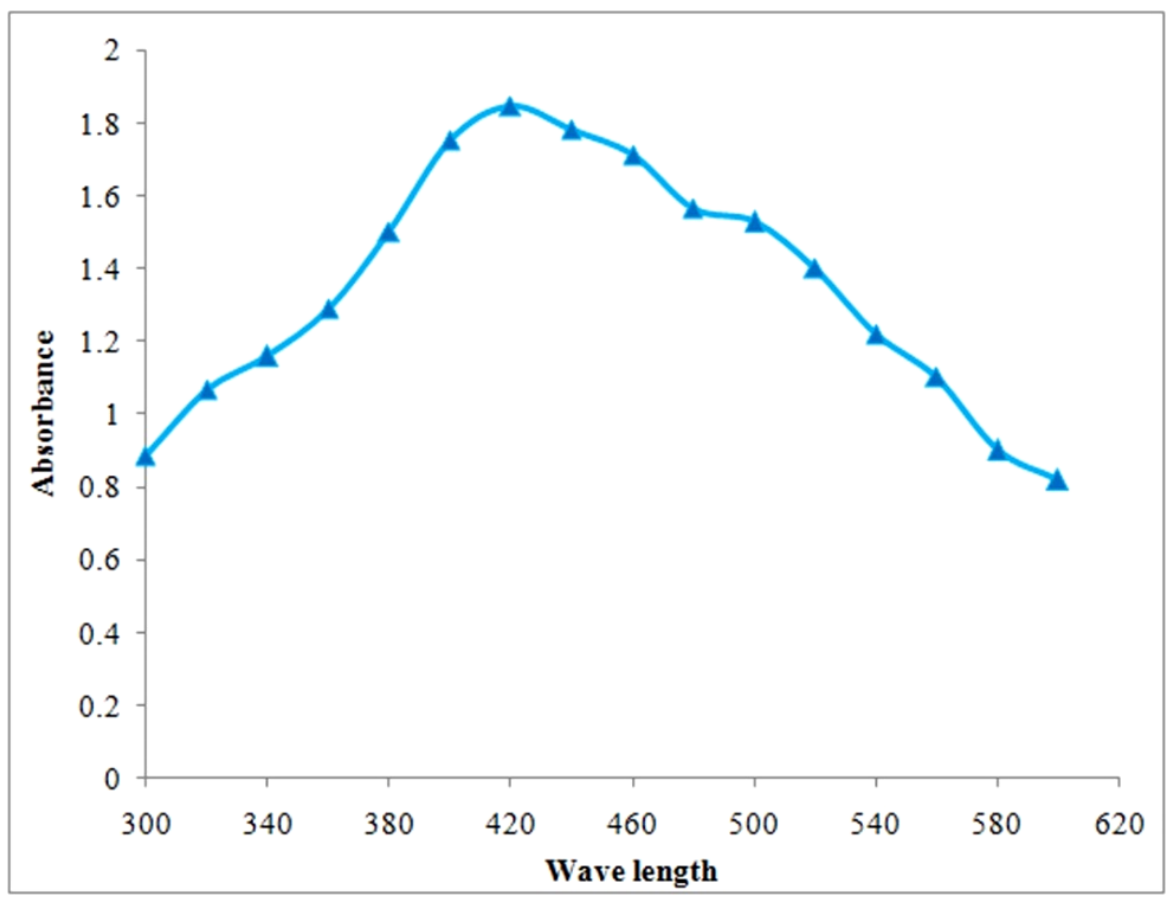

Fig. 1: UV-vis spectra of Cymodocea rotundata extract containing AgNPs. 


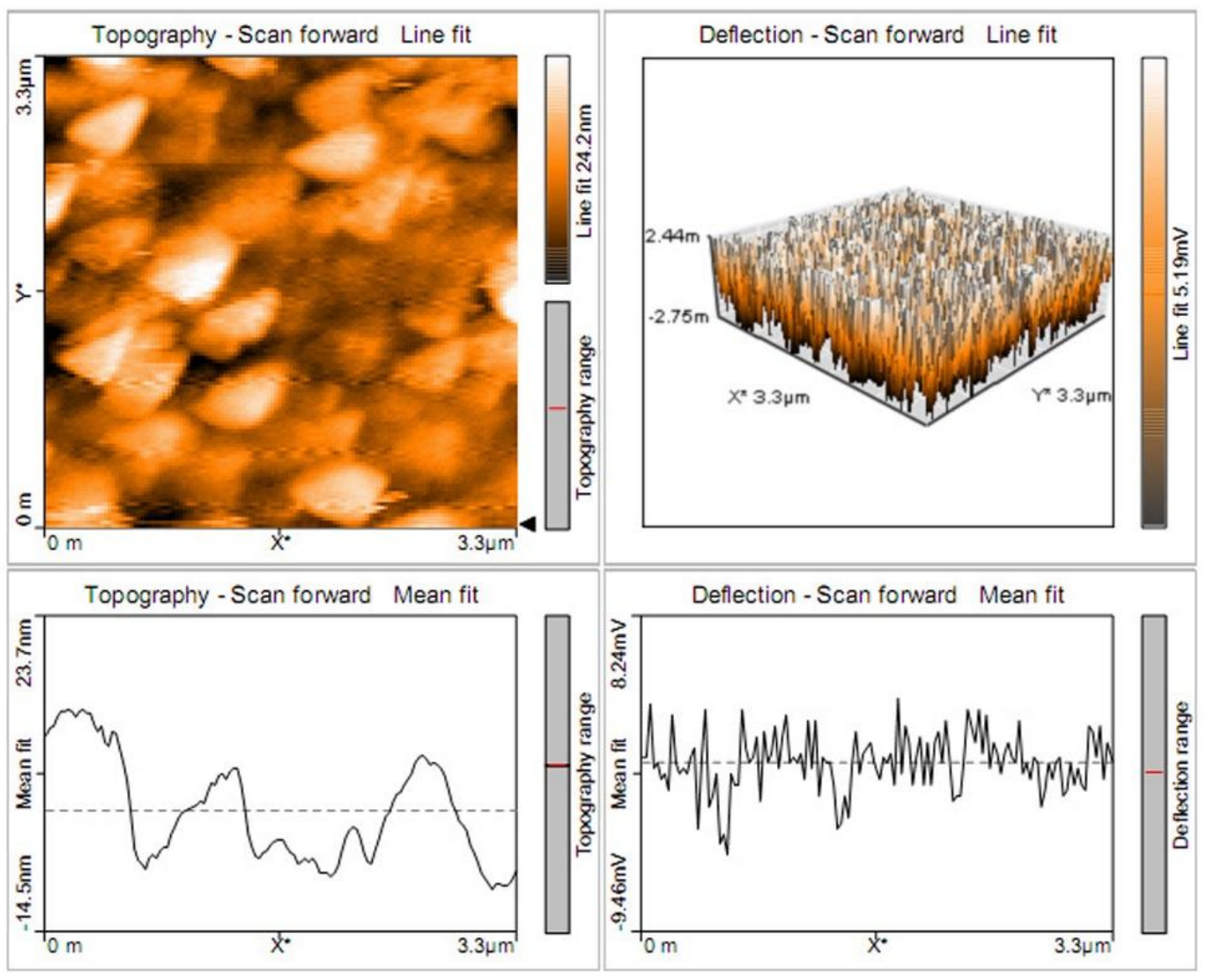

Fig. 2: AFM image of AgNPs.
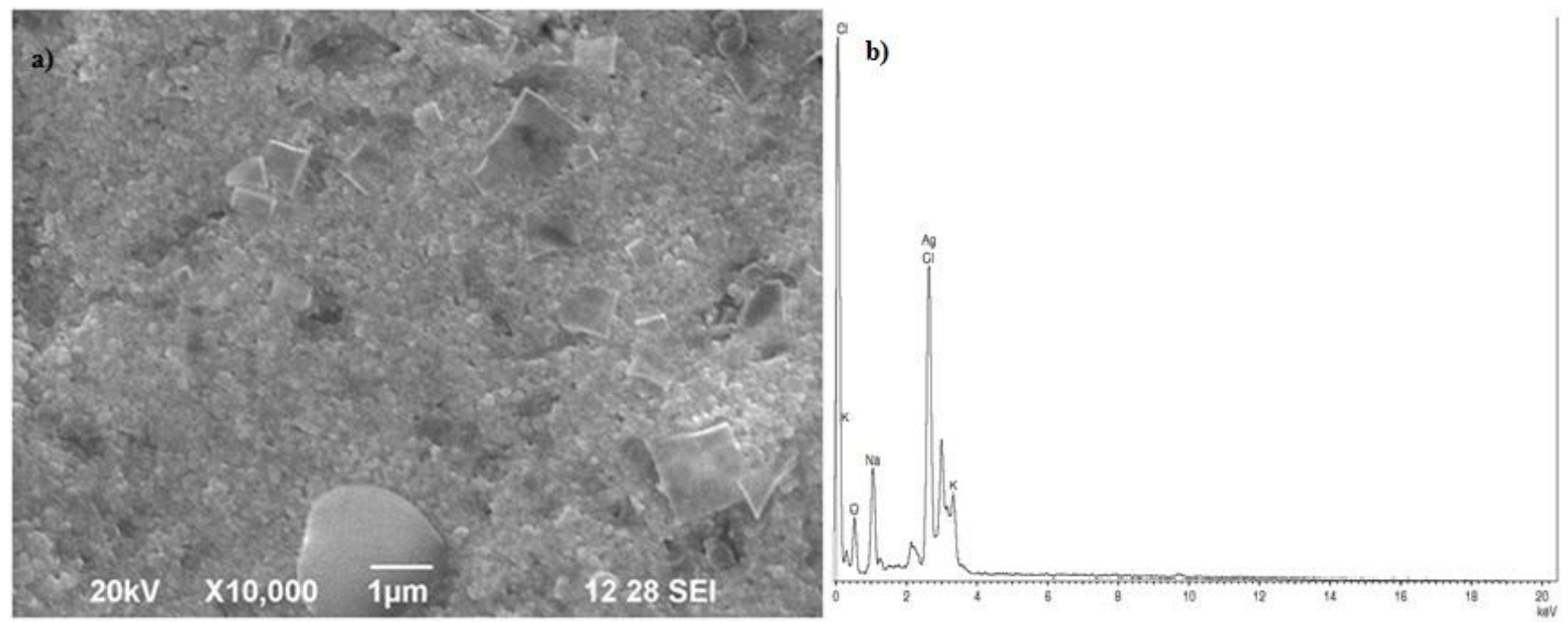

Fig. 3: (a) SEM image of AgNPs and (b) EDX spectrum of AgNPs. 


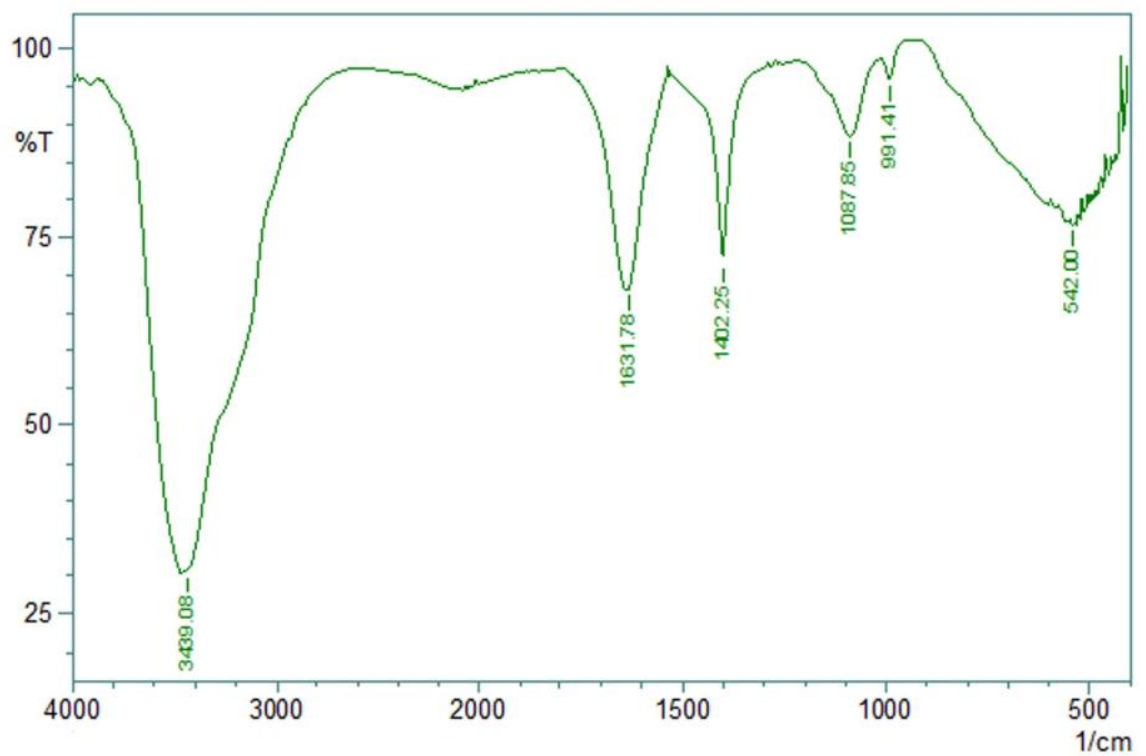

Fig. 4: FTIR spectra of AgNPs.

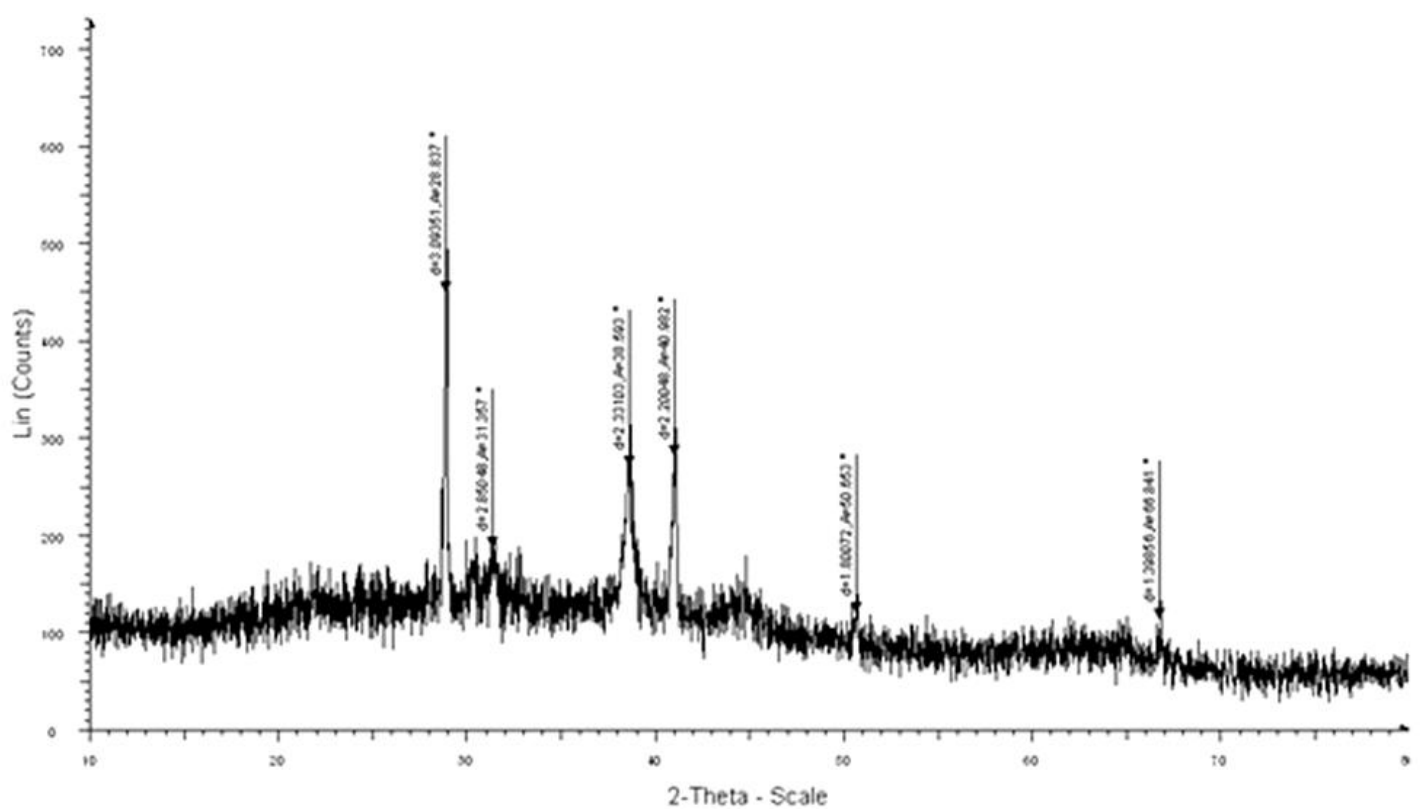

Fig. 5: XRD pattern of AgNPs exhibiting the facets of crystalline silver.

Antioxidant activity of AgNPs was assessed by DPPH scavenging assay by using ascorbic acid as positive control. DPPH is a stable compound and accepts hydrogen or electrons from $\mathrm{Ag}$ NPs. The results obtained in the DPPH assay showed effective free radical inhibition by AgNPs. The average percentage inhibition of synthesized AgNPs was found to be $77.3 \%$ and the activity was increased with increasing concentrations of AgNPs. Similar observations with enhanced DPPH scavenging activity by selenium, platinum, silver nanoparticles and by torolex and chitosan coated gold nanoparticles have been reported (Ramamurthy et al., 2013). The reducing activity of AgNPs was found to be increased with increasing concentrations.
Similar observations were made by Dipankar and Murugan (2012) with AgNPs synthesized by Iresine herbstii.

Antimicrobial activity of AgNPs was investigated against various pathogenic organisms using the well diffusion method. The highest antimicrobial activity of AgNPs was found against $K$. pneumoniae $(13 \mathrm{~mm})$ followed by Enterococcus $\mathrm{sp} .(12 \mathrm{~mm})$ and the lesser antimicrobial activity was found against $S$. aureus with inhibition zone of $11 \mathrm{~mm}$. Recently, Sankar et al. (2013) reported the silver nanoparticles showed more than $10 \mathrm{~mm}$ zone of inhibition against E. coli, Aeromonas hydrophila, Salmonella sp., and $S$. paratyphi. The highest antimicrobial activity was observed against Pseudomonas aeruginosa $(16 \mathrm{~mm})$. The lesser 


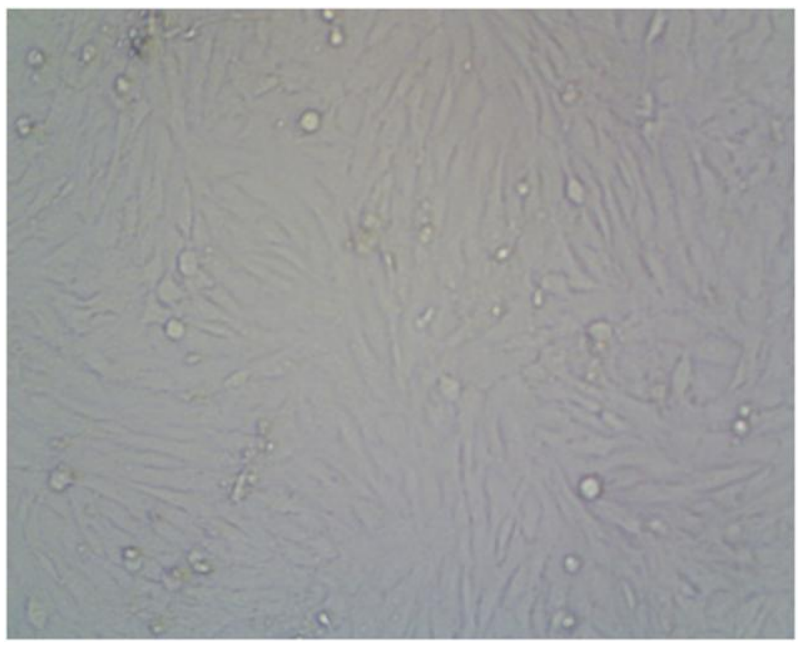

Fig. 6: Image of osteosarcoma cell line MG63 treated with AgNPs.

antimicrobial activity of silver nanoparticles synthesized by both Citrus sinensis and Centella asiatica against Staphylococcus aureus was $8 \mathrm{~mm}$ and Escherichia coli was $8 \mathrm{~mm}$.

In vitro cytotoxicity of the silver nanoparticles was evaluated against human osteosarcoma cell line MG 63 at different concentrations (12.5-200 $\mathrm{g} \mathrm{m} \mathrm{m}^{-1}$ ) by MTT-assay (Figure 6). In relation to cell death, a minimum of $25 \mu \mathrm{g} \mathrm{ml}{ }^{-1}$ of AgNPs was enough to induce $47.61 \%$ of cell mortality. In the present study, the AgNPs were able to inhibit the growth of cell line by $6.76 \%$ at low concentration. In contrast, the presence of $50 \mu \mathrm{g} \mathrm{ml}^{-1}$ of AgNPs significantly inhibited the cell growth by $100 \%$. The $\mathrm{IC}_{50}$ value for AgNPs was calculated and it was found to be $25.31 \mu \mathrm{g}$ $\mathrm{ml}^{-1}$. A few in vitro studies analyzed the translocation of AgNPs in cancer cell line with a $\mathrm{LD}_{50}$ value of $300 \mu \mathrm{g} \mathrm{ml}^{-1}$ (Sriram et al., 2010).

The AgNPs may induce reactive oxygen species and cause damage to cellular components leading to cell death (Jacob et al., 2012). Never the less, this is the first report on cytotoxic effects of green synthesized AgNPs using Cymodocea rotundata extract against human osteosarcoma MG63 cells.

\section{CONCLUSIONS}

To conclude, we report a simple, speedy and efficient green synthesis of AgNPs from the Cymodocea rotundata extract. The characterization with UV-vis spectroscopy, FTIR, AFM, SEM and XRD analysis evidence the formation of nanoparticles. The synthesized AgNPs is substantiated by their potent free radical quenching effect and antimicrobial activity against human pathogenic bacterial strains. In the present study, in vitro cytotoxic activity of green synthesized AgNPs against human osteosarcoma MG63 cell line was remarkable with $47.61 \%$ of mortality at $25 \mu \mathrm{g}$ $\mathrm{ml}^{-1}$.

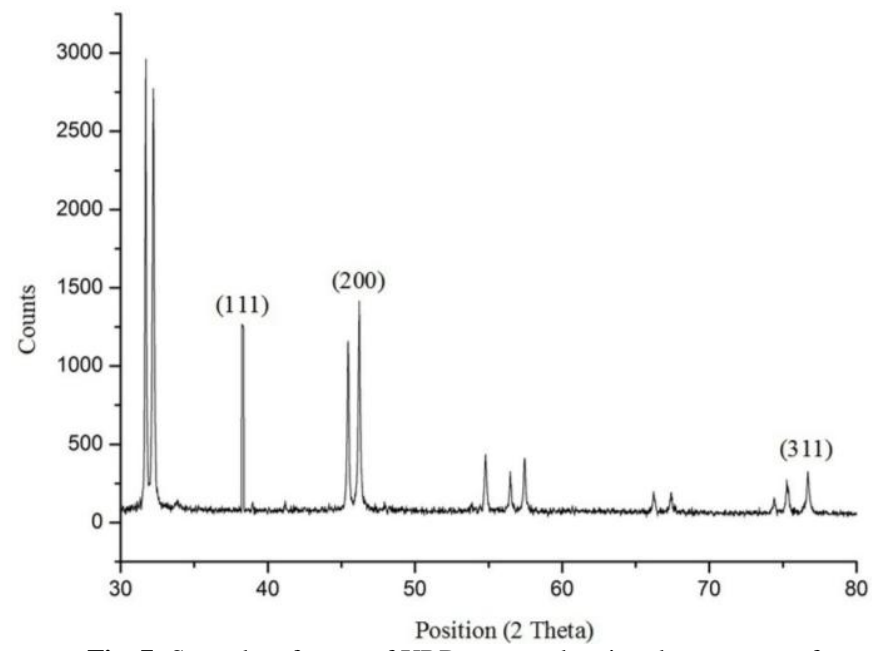

Fig. 7: Smoothen format of XRD pattern showing the presence of different peaks on 2 theta plane indicating the crystalline structure of the synthesized AgNPs.

\section{Financial support and sponsorship: Nil.}

Conflict of Interests: There are no conflicts of interest.

\section{REFERENCES}

Abdel-Aziz MS, Shaheen MS, El-Nekeety AA and AbdelWahhab MA. Antioxidant and antibacterial activity of silver nanoparticles biosynthesized using Chenopodium murale leaf extract. J Saudi Chem Soc, 2014; 18(4): 356-363.

Bhattacharya D, Rajinder G. Nanotechnology and potential of microorganisms. Crit Rev Biotechnol, 2005; 25: 199-204.

Chakraborty P and Abraham J. Antimicrobial and Cytotoxic Effects of Macrotyloma uniflorum Extract. IJPPR, 2016; 8(8): 1334-1340.

Chakraborty P, Dam D, Abraham J. Bioactivity of Lanthanum Nanoparticle Synthesized using Trigonella foenum-graecum Seed Extract. J Pharm Sci \& Res, 2016; 8(11): 1253-1257.

Dipankar C and Murugan S. The green synthesis, characterization and evaluation of the biological activities of silver nanoparticles synthesized from Iresine herbstii leaf aqueous extracts. Colloids Surf B, 2012; 98: 112-119.

Gole A, Dash C, Ramachandran V, Sainkar SR, Mandale AB, Rao M, Sastry M. Pepsin-gold colloid conjugates: preparation, characterization, and enzymatic activity. Langmuir, 2001; 17(5): 16741679.

Gong P, Li H, He X, Wang K, Hu J, Tan W. Preparation and antibacterial activity of $\mathrm{Fe} 3 \mathrm{O} 4$ and $\mathrm{Ag}$ nanoparticles. Nanotechnol, 2007; 18: 604-611.

Jacob SJP, Finub JS, Narayanan A. Synthesis of silver nanoparticles using Piper longum leaf extracts and its cytotoxic activity against Hep-2 cell line. Colloids Surf B, 2012; 91: 212-214.

Jae YS, Beom SK. Rapid biological synthesis of silver nanoparticles using plant leaf extracts. Bioprocess Biosyst Eng, 2009; 32: $79-84$.

Korbekandi H, Ashari Z, Iravani S and Abbasi S. Optimization of biological synthesis of silver nanoparticles using Fusarium oxysporum. Iran J Pharm Res, 2013; 12(3): 289-298.

Logeswari P, Silambarasan S, Abraham J. Ecofriendly synthesis of silver nanoparticles from commercially available plant powders and their antibacterial properties. Sci Iran, 2013; 20(3): 1049-1054.

Lu HW, Liu SH, Wang XL, Qian XF, Yin J, Jhu JK. Silver nanocrystals by hyperbranched polyurethane-assisted photochemical reduction of $\mathrm{Ag}^{+}$. Mater Chem Phys, 2003; 81: 104-107. 
Monks A, Scudiero D, Skehan P, Shoemaker R, Paull K, Vistica D, Hose C, Langley J, Cronise P, Vaigro-Wolff A, Gray-Goodrich M. Feasibility of a high-flux anticancer drug screen using a diverse panel of cultured human tumor cell lines. J Natl Cancer Inst, 1991; 83(11):757-66.

Mosmann T. Rapid colorimetric assay for cellular growth and survival: application to proliferation and cytotoxicity assays. J Immunol Methods. 1983; 65(1-2): 55-63.

Rai M, Yadav A, Gade A. Silver nanoparticles as a new generation of antimicrobials. Biotechnol Adv, 2009; 27: 76-83.

Ramamurthy $\mathrm{CH}$, Padma M, Samadanam IDM, Mareeswaran R, Suyavaran A, Suresh Kumar M, Premkuar K, Thirunavukkarasu C. The extra cellular synthesis of gold and silver nanoparticles and their free radical scavenging and antibacterial properties. Colloid Surf B, 2013; 102: 808-815.

Sankara R, Karthika A, Prabua A, Karthika S, Shivashangari KS, Ravikumara V. Origanum vulgare mediated biosynthesis of silver nanoparticles for its antibacterial and anticancer activity. Colloids Surf B, 2013; 108: 80-84.

Sriram MI, Kanth SBM, Kalishwaralal K, Gurunathan S. Antitumor activity of silver nanoparticles in Dalton's lymphoma ascites tumor model. Int J Nanomed, 2010; 5: 753-762.

Thirunavoukkarasu M, Balaji U, Behera S, Panda PK, Mishra BK. Biosynthesis of silver nanoparticle from leaf extract of Desmodium gangeticum (L.) DC. and its biomedical potential. Spectrochimica Acta A Mol Biomol Spectrosc, 2013; 116: 424-427.

\section{How to cite this article:}

Abraham J, Saraf S, Mustafa V, Chaudhary Y, Sivanangam S. Synthesis and evaluation of silver nanoparticles using Cymodocea rotundata against clinical pathogens and human osteosarcoma cell line. J App Pharm Sci, 2017; 7 (06): 055-061. 